\section{Ecology benefits from decay}

Sofia. Historians of ancient Thrace (whose research institute the BAS has closed) will tell you that the Bulgarians' ancestors were carefree, almost lazy; they sang, danced, and had plenty of holidays. So, the story goes, they were the last to ask for their land when God was distributing it. The Almighty by then had none left, and was forced to give them some he had reserved for himself.

That is the only explanation why Bulgaria possesses everything: mountains and valleys, sea and rivers, forests and fields covered by blossoming roses; why it occupies the crossroads between north and south, east and west.

True or not, that gives science a target: to use all means, theoretical and experimental, to save this God-chosen land. That, at least, is how Dr Yordan Uzunov sees his role. As a senior researcher at the Institute of Ecology of the BAS and Deputy Minister of the Environment, he uses both scientific and administrative approaches.

Uzonov even believes that the present situation provides a unique opportunity. "Today's dormant industry and agriculture pollute neither water nor air. . . the ecological situation is now better than anyone can remember." He says the task will be to maintain that state of affairs when the economy revives. Unfortunately, the percentage of GNP allocated to ecology is also falling: in 1992 it was 0.45 per cent, in 19930.4 per cent, and this year only 0.29 per cent.

And there are not roses everywhere. As a remote province of the old Eastern bloc, Bulgaria had to carry out ecologically hazardous production for the rest of the empire. One example is uranium mining. Economically, it was absurd. The cost across the globe of producing a kilogram of concentrated non-enriched uranium is between US\$17 and US\$26, but in Bulgaria it is US\$250. It would have been much cheaper to mine uranium in Armenia.

But political reasoning, and the wish to move 'dirty' production to the periphery, won. Now Bulgaria will require US\$160 million and $10-15$ years to recultivate land currently enclosed by barbed wire.

The other ecological problem is energy production. Bulgaria has hardly any naturally occurring oil or gas, and its coal is of poor quality. Of the country's electricity, 46 per cent comes from a nuclear power station in Kozlodui. But 47 per cent of the population is afraid of radioactivity and 70 per cent think the government is deceiving them by using a second nuclear power station, built secretly and well-hidden.

Opinion has been powerfully influenced by people such as the French oceanographer Yves Cousteau, who visited Bulgaria to protest against the opera- tion of Kozlodui. He is believed to have ceased campaigning after the Kozlodui station bought some French equipment. But as things are now, proper station maintenance is impossible.

The National Ecological Foundation, founded in March 1993, is not helping matters. It is supposed to collect money from those polluting the environment, but everyone manages to postpone paying fines. The foundation's revenues instead come largely from duties levied on the owners of older cars.

As always, Bulgaria's position at the crossroads of Europe brings Bulgaria both trouble and income - the flow of such cars through the country is considerable. Last year, NEF collected 108 million leva in this way, returning 67 million leva to local government organizations for the improvement of the ecological situation.

But that is a drop in the ocean. Bulgaria hopes to take the route already followed by 16 other countries of trading foreign debt for domestic spending on ecological projects. Poland is the envied example in this part of the world. A fraction of Bulgaria's US\$14-billion foreign debt thus converted could do a great deal for environmental protection. But Bulgaria differs from Poland in that its main creditors are not other governments but private banks and companies not overly concerned with ecology.

C.L.

\section{World Cup - an excuse to celebrate} Foreign countries have always played an important role in Bulgarian science. The Bulgarian Academy of Sciences was itself founded abroad - as recounted by the president of the Romanian Academy (page 608).

After the liberation of Bulgaria in 1911, that became the Academy of Sciences, which celebrated its 125th anniversary on 12 October this year, a few weeks before the 125th anniversary of Nature. The president of Bulgaria, Zheliu Zhelev, and the director general of UNESCO, Dr Federico Mayor, were both present.

Many Bulgarians considered the celebrations to be an unaffordable luxury, but accepted that the presumed wishes of the nation's ancestors should be taken into account. The winning by the Bulgarian team of the bronze medal at the World Cup football championship in July led to a nationwide festival. Not everyone here is a soccer lover, but most are tired and desperately need a pretext for celebration. Why should not the events of this October give Bulgarian science a new impetus?

\section{A phoenix flies}

Sofia. Enterprise may be an unfamiliar plant in Bulgaria, but it can sometimes flourish marvellously.

Perhaps the best example is Orbita, a 16-page weekly founded in 1969 and for decades the only paper in Eastern and Central Europe completely dedicated to science. It was one of the country's four most popular publications, with a peak circulation of more than 160,000 in 1990 .

But in the autumn of 1991, it was closed by its publishing house, owned by the recently defunct Young Communist League. The very next day, the editorial staff produced that week's edition, newly registered in strict accordance with the law, which gave their subsidiary private firm Omega the right to publish a weekly now called Nova Orbita.

The money they had managed to save allowed them to continue for a month or two until they were rescued by two truly wealthy firms, Diamex and Dizal, and two private individuals, Petko Todorov and Slavcho Ivanov. Now a new enterprise called Diomega produces the newspaper.

But still there is not enough money, with the result that Nova Orbita is subsidized by publishing a magazine containing crosswords, puzzles and the like, and by selling advertising space. The staff consists of only 6 people compared with the former 35 . Everybody has to work hard.

Yet there are some benefits in this arrangement. Nikolai Katranjiev, one of the editors and now the owners, of Nova Orbita, has a favourite joke: "Life is easier for a one-legged man: he only needs one boot".

C.L.

\section{Attrition in change}

Sofia. Nothing changes, but everything is different. People here still shake their heads for "yes" and nod for "no", but what they affirm or reject by so doing has changed. Four years ago, Nature reported from Sofia that "... the Red Star atop party headquarters [in Lenin Square in central Sofia] is not going to be pulled down any time soon" (344, 618-620; 1990).

But now the star has gone. The stars have even disappeared from the epaulettes of soldiers and police, to be replaced by the politically neutral rhombus. Lenin's name on all the street-signs in the square has been replaced by that of Baba Nedelya, an historical character of the Renaissance. And people in Bulgaria can no longer be accused of inactivity.

That certainly holds true for the scientific community; 5,000 of the previous 15,000 people connected to the (BAS), have left in the past five years. 